\title{
The Chemical Modification of Cellulase Obtained from Bacillus subtilis ITBCCB148 With Dimethyladimipidate
}

\author{
Yandri, Putri Amalia, Tati Suhartati and Sutopo Hadi \\ Department of Chemistry, University of Lampung, Jl. S. Brojonegoro No. 1 \\ Gedongmeneng Bandar Lampung 35145
}

DOI: http://dx.doi.org/10.13005/bbra/1877

(Received: 20 September 2015; accepted: 07 November 2015)

\begin{abstract}
Cellulase obtained from Bacillus subtilis ITBCCB148 has successfully been isolated and purified. The native enzyme was modified with dimethyladipimidate (DMA) to increase the stability of the enzyme. The native and modified enzymes were characterized including determination of optimum temperature, optimum $\mathrm{pH}$ and thermal stability. The activity of the cellulase was determined based on Mendels method and the protein content was determined based on Lowry method. The results showed that the native enzyme has optimum temperature of $55^{\circ} \mathrm{C}$ and optimum $\mathrm{pH}$ of 5.5 . The thermal stability for 60 minutes at temperature of $55^{\circ} \mathrm{C}$ indicated that the native enzyme has $\mathrm{k}_{\mathrm{i}}=0.034$ min. $\mathrm{t}^{-1}, \mathrm{t}_{1 / 2}=20.4 \mathrm{~min}$., and $\Delta \mathrm{G}_{\mathrm{i}}=100.9 \mathrm{~kJ} / \mathrm{mol}$. The modified enzyme with modification degrees of $64.5 ; 69.5$ and $82 \%$ have optimum temperature of $55^{\circ} \mathrm{C}$ and optimum $\mathrm{pH}$ of 6 . The thermal stability for 60 minutes at temperature of $55^{\circ} \mathrm{C}$ of the modified enzyme with modification degrees of 64.5 ; 69.5 and $82 \%$ have $k_{i}$ values of $0.024 ; 0.021$ and 0.022 min. ${ }^{1}, t_{1 / 2}$ values of $28.9 ; 33.0$ and 31.5 minutes, and $\Delta G_{i}$ values of $101.9 ; 102.3$ and $102.2 \mathrm{~kJ} /$ mol, respectively. The modification with DMA has successfully increased the thermal stability of the modified enzymes between 1.4 - 1.6 times compared to that of the native enzyme. The decrease of ki values, increase of half-lives and $\Delta G_{i}$ indicated that the modified enzymes were more stable compared to the native enzyme.
\end{abstract}

Key words: Cellulase, Bacillus subtilis ITBCCB148, dimethyladimipidate.

The research on the enzyme stability is very interesting in the last decade due to the developing in industry, especially in detergent industry, liquid sugar syrup from amylum, synthetic organic compound industry, pulp and paper industry, feed stock industry and the use of the this enzyme in the treatment of industrial waste $^{1}$.

Enzyme in general is not stable at high temperature and extreme $\mathrm{pH}^{2}$, the condition which generally required at many industrial processes. Therefore, the thermostable enzymes are needed,

\footnotetext{
* To whom all correspondence should be addressed. E-mail: yandri.as@fmipa.unila.ac.id
}

the enzymes which are able to work optimum at temperature range of $60^{\circ}-125^{\circ} \mathrm{C}^{1}$ and wide range of $\mathrm{pH}$. To obtain the enzyme having high stability and activity at extreme condition, it can be achieved by direct isolation from natural organism living at that condition (extremophilic) or by chemical modification toward enzyme obtained from organism living at normal condition (mesophilic) ${ }^{3}$.

According to Mozhaev and Martinek ${ }^{4}$ the stabilization of enzyme obtained from mesophilic microbia is more preferable to obtain more stable enzyme since the direct isolation from thermophilic enzyme have some weaknesses such as requiring bioreactor design or new process method ${ }^{5}$. Mozhaev and Martinek ${ }^{4}$ reported three ways for enzyme stabilization including immobilization, chemical modification and directed mutagenesis. Enzyme immobilization has some disadvantages as 
there will be decreased on binding capacity or enzyme reactivity due to mass transfer inhibition by immobile matrix. Directed mutagenesis requires complete information about the primier structure and complete image of the three dimentional structure. Thus, chemical modification is the more preferable method to obtain the more stable enzyme.

According to Mozhaev et al. ${ }^{6}$ to obtain the modified enzyme with stable covalent bond can be achieved by (1) modification using bifunctional reagent to form cross-linking bond among the functional groups on the surface of protein; (2) modification using nonpolar reagent to increase hydrophobic interaction; (3) addition of charge groups or polar group to increase the ionic or hydrogen bonds; (4) hydrophilisation of protein surface to protect contact between hydrophoic groups and aqueous surrounding which is not preferred by the enzyme. Mozhaev and Martinek ${ }^{4}$ stated that to increase the stability of the enzyme, chemical modification is the method chosen. The increase of enzyme stability can be achieved by the addition of a certain material. Chemical modification by cross linking or bifunctional reagent is a very useful method to increase stability of protein at thermal condition. The cross linking produces folding conformation of native enzyme and reduce thermal inactivation? ${ }^{7}$. One the bifunctional reagent used is dimethyladipimidate (DMA) ${ }^{7}$.

In our previous research, it has been performed chemical modification on á-amylase obtained from $B$. subtilis ITBCCB148 using dimethyladipimidate. The results showed that all modified enzymes increased their thermal stability compared to the native enzyme ${ }^{8}$. The cellulase obtained from B. subtilis ITBCCB148 has also been modified using low molecular weight modifier of glyoxylic acid ${ }^{9}$. The results showed that the modification was able to increase the thermal stability of the modified enzymes between 1.8-2.1 times compared to the native enzyme. In this paper we continue to perform chemical modification on native cellulase using dimethyladipimidate as modifier in order to increase its stability. The characterization to native and modified enzymes were also performed by varying temperature, $\mathrm{pH}$ and thermal stabiltiy.

\section{MATERIALSANDMETHODS}

\section{Materials}

All chemicals used were of high grade (pro analysis) materials. Bacteria isolate B. Subtilis ITBCCB148 was obtained from Microbiology and Bioprocess Technology Laboratory, Chemical Engineering Department, Bandung Institute of Technology, Bandung, Indonesia.

\section{Research procedure}

The following research phases were performed: the production, isolation, purification and characterization of the native enzyme were based on our previous report ${ }^{10}$.

Activity test of cellulase and determination of protein content

Activity of cellulase was determined using dinitrosalycylic acid ${ }^{11}$. The protein content was determined based on the method by Lowry et al. ${ }^{12}$.

Chemical modification of the native enzyme using dimethyladipimidate (DMA)

To $10 \mathrm{~mL}$ of native cellulase in $0.1 \mathrm{M}$ buffer borate $\mathrm{pH} 8$ was added with solid DMA with concentration variation of 5, 10 and $15 \mathrm{mg}$. The mixture was magnetically stirred at room temperature for $1 \mathrm{~h}^{13}$.

\section{Determination of Modification Degree}

Modification degree was determined using method developed by Synder and Sobocinski ${ }^{14}$.

Characterization of enzyme before and after modification

Determination of optimum temperature

The determination of optimum temperature was performed by varying the temperature at $55,60,65,70,75$ and $80^{\circ} \mathrm{C}$.

\section{Determination of optimum $\mathrm{pH}$}

Determination of optimum $\mathrm{pH}$ was performed by varying $\mathrm{pH}$ at $5 ; 5.5 ; 6 ; 6.5 ; 7 ; 7.5 ; 8$; 8.5; 9 .

\section{The thermal stability test of enzyme}

The thermal stability of native and modified enzymes was performed by measuring the residual activity of the enzyme after being incubated for $0,10,20,30,40,50$, and 60 minutes at temperature of $55^{\circ} \mathrm{C}^{15}$.

Determination of half life $\left(t^{1} / 2\right), k_{i}$ and $\Delta G i$

Determination of $k_{i}$ value (thermal inactivation rate constant) of the enzyme was 
performed using the first order of inactivation kinetics equation (Eq. 1)

$$
\ln \left(\mathrm{E}_{\mathrm{i}} / \mathrm{E}_{0}\right)=-\mathrm{k}_{\mathrm{i}} \mathrm{t}
$$

The change of energy due to denaturation was performed using Equation $2^{7}$.

$$
\Delta \mathrm{G}_{\mathrm{i}}=-\mathrm{RT} \ln \left(\mathrm{k}_{\mathrm{i}} \mathrm{h} / \mathrm{k}_{\mathrm{B}} \mathrm{T}\right)
$$

\section{RESULTS AND DISCUSSIONS}

\section{Determination of modification degree}

The modification of the native enzyme with DMA was performed with 3 concentration variation i.e. 5, 10 and $15 \mathrm{mg}$ as shown in Table 1. The determination of modification degree was based on the comparison of lysine residue before and after the modification. The data in Table 1 indicated that the modification with DMA with concentration of 5, 10 and $15 \mathrm{mg}$ produced modification degree of $64.5 ; 69.5$ and $82 \%$, respectively. The calculation of the modification degree was based on the comparison of the number of lysine residues which were not modified at the modified enzymes and native enzyme. The ammine group on the lysine residues which were not modified will react with TNBS reagent to form yellow complex. The more the ammine group on the lysine residue were modified, the less the ammine group will react with TNBS, as a result the complex will be pale yellow. Based on Table 1, the higher concentration of DMA, the higher the modification degree.

\section{Determination of optimum temperature}

Fig. 1 showed that the optimum temperature of the native and modified enzymes was the same, i.e. at $55^{\circ} \mathrm{C}$. All modified enzymes were observed to be more stable compared to the native enzyme at temperature range $50-65^{\circ} \mathrm{C}$. The data in Fig. 1 indicated that the modified enzymes with modification degree of $64.5 ; 69.5$ and $82 \%$ at

Table 1. Determination of Modification Degree with TNBS

\begin{tabular}{lcc}
\hline Sample & $\begin{array}{c}\Delta \mathrm{A}_{420} \\
\mathrm{~nm}\end{array}$ & $\begin{array}{c}\text { Modification } \\
(\%)\end{array}$ \\
\hline Native Enzyme & 0.5858 & 0 \\
Modified with DMA 5 mg & 0.5714 & 64.5 \\
Modified with DMA 10 mg & 0.5703 & 69.5 \\
Modified with DMA 15 mg & 0.5675 & 82 \\
\hline
\end{tabular}

$55^{\circ} \mathrm{C}$ have \% activity of 93, 94 and 95\%, respectively, while the native enzyme was $76 \%$. At $65^{\circ} \mathrm{C}$ the similar result was also observed where the modified enzymes had \% activity of 72,78 and $90 \%$, while the native enzyme had $58 \%$. At $70^{\circ} \mathrm{C}$, the modified enzymes were shown to be much better with \%activity of 57, 68 and $89 \%$ while the native enzyme was only $40 \%$. The results obtained indicated that there was an increased on the enzyme stability to the modified enzymes at higher temperature compared to the native enzyme, although the increase of optimum temperature was not observed. The results obtained similar to those reported by others ${ }^{7,16}$. that the chemical modification was not always cause the optimum temperature increase, rather the increase of the enzyme stability.

\section{Determination of Optimum pH}

Fig. 2 showed that the native and modified enzymes have working $\mathrm{pH}$ range of $5-7.5$. The optimum $\mathrm{pH}$ of the native enzyme was 5.5 and the modified enzymes were 6 , thus there was a slight increased in the optimum temperature. The data in Fig. 2 also indicated the increase of enzyme stability for the modified enzyme compared to the native enzyme especially the modified enzyme with modification degree of 69.5 and $82 \%$. At $\mathrm{pH} 6.5$, these two modified enzyme have \% activity of 96 and $97 \%$, while the native enzyme was $82 \%$. At pH 9 , the $\%$ activities of these two modified enzymes were 73 and $75 \%$, while the native enzyme was only $59 \%$. Based on these data, it can be concluded that the cross linking formation using DMA was able to increase the stability of the enzyme against $\mathrm{pH}$.

\section{Thermal Stability of the enzyme}

The data on Fig. 3 shown that the native enzyme has residual activity (\%) $14.1 \%$ after being incubated at $55^{\circ} \mathrm{C}$ for 60 minutes, while the modified

Table 2. The change of Inactivation rate constant $\left(\mathrm{k}_{\mathrm{i}}\right)$, half life $\left(\mathrm{t}_{1 / 2}\right)$, and energy due to denaturation $\left(\Delta \mathrm{G}_{\mathrm{i}}\right)$ of the enzymes

\begin{tabular}{lccc}
\hline Enzyme & $\begin{array}{c}\mathrm{ki} \\
\left(\mathrm{min}^{-1}\right)\end{array}$ & $\begin{array}{c}\mathrm{t}_{1 / 2} \\
(\text { minute) }\end{array}$ & $\begin{array}{c}\Delta \mathrm{Gi} \\
(\mathrm{kJ} / \mathrm{mol})\end{array}$ \\
\hline Native & 0.034 & 20.4 & 100.9 \\
DMA 64.5\% & 0.024 & 28.9 & 101.9 \\
DMA 69.5\% & 0.021 & 33.0 & 102.3 \\
DMA 82\% & 0.022 & 31.5 & 102.2 \\
\hline
\end{tabular}


enzymes with modification degree of (64.5; 69.5 and $82 \%$ ) have 25.7; 26.1 and 26.7, respectively. All modified enzymes have increased their thermal stability against temperature compared to the native enzyme.

Half life $\left(t_{1 / 2}\right)$, thermal inactivation constant $\left(k_{i}\right)$, and the change of energy due to denaturation $\left(\Delta G_{i}\right)$

Table 2 tabulated the data of half life $\left(\mathrm{t}_{1 / 2}\right)$, thermal inactivation constant $\left(\mathrm{k}_{\mathrm{i}}\right)$, and the change

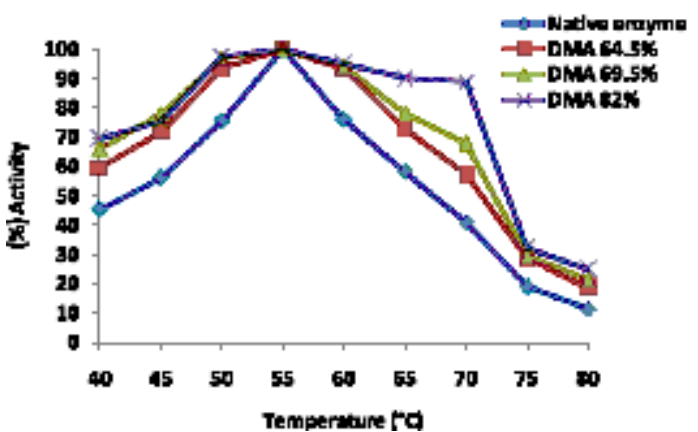

Fig. 1. Optimum temperature of purified and modified enzyme (64.5; 69.5 and 82\%)

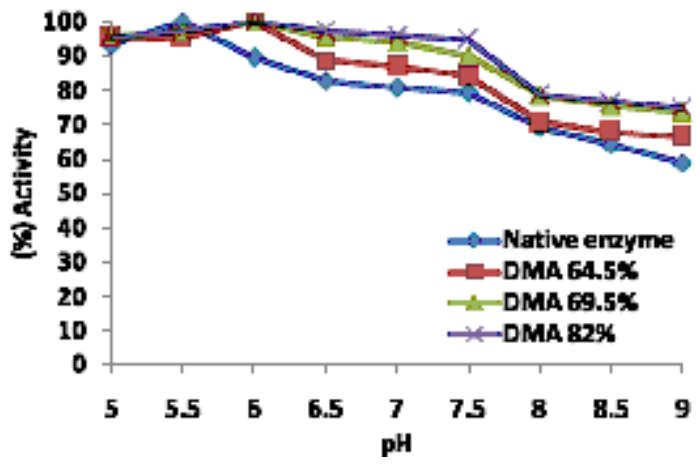

Fig. 2. Optimum $\mathrm{pH}$ of native and modified enzymes (64.5; 69.5 and 82\%)

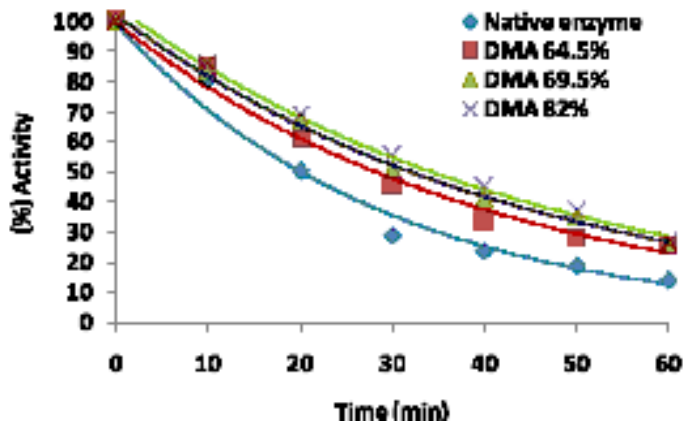

Fig. 3. Thermal stability of the native enzyme and modified enzyme (64.5; 69.5 and 82\%). At temperature $55^{\circ} \mathrm{C}$ vs time of energy due to denaturation $\left(\Delta \mathrm{G}_{\mathrm{i}}\right)$

Based on the data on Table 2, it can be seen that the half life $\left(t_{1 / 2}\right)$ of modified enzymes were increased $1.4-1.6$ than the native enzyme. According to Sthal ${ }^{17}$, the increase of half life will determine the stability of the enzyme. The result obtained indeed indicated that the stability of the modified enzymes were higher than the native enzyme.

In conclusion, the chemical modification using DMA on cellulase obtained from $B$. subtilis has successfully increased the thermal stability of the native enzyme. The thermal stabilities of the modified enzymes were increased $1.4-1.6$ times compared to the native enzyme. The decrease of $\mathrm{k}$ value, the increase of half-life and $\ddot{A} G_{i}$ values showed that the modified enzymes were more stable than the native enzyme.

\section{ACKNOWLEDGMENTS}

The authors would like to thank The Directorate of Research and Community Services, Directorate General of Higher Education, The Ministry of Research, Technology and Higher Education of Republic of Indonesia that provided funds for this project to be undertaken through the Competency Grant Research Scheme (Penelitian Hibah Kompetensi) 2015 with contract number 162/UN26/8/LPPM/2015, 30 March 2015.

\section{REFERENCES}

1. Vieille C. and Zeikus J. G., Tibtech., 1996; 14: 183.

2. Goddettee D.W., Terri C., Beth F.L., Maria L.,Jonathan R.M., Christian P., Robert B.R., Shiow S.Y. and Wilson C.R., J. Biotechnol., 1993; 28: 41.

3. Wagen E.S., Strategies for increasing the stability of enzymes, in Enzyme Engineering 7, The New York Academy of Sciences, New York, 1984; 119 .

4. Mozhaev V.V. and Martinek K., Enzyme Microb. Technol., 1984; 6: 50.

5. Janecek S., Process Biochem., 1993; 28: 435.

6. Mozhaev V.V., Melik-Nubarov, N.S. , Siksnis, V. and Martinek, K., Biocatalysis, 1990; 3: 189.

7. Kazan D., Ertan H. and Erarslan A., Appl. Microbiol. Biotechnol., 1997; 48: 191.

8. Yandri, Apriyanti, Suhartati, T. and Hadi, S., Biosci. Biotechnol. Res.ih Asia, 2010; 7(2): 713. 
9. Yandri, Rachmawati,R., Suhartati, T. and Hadi, S., J. Pure Appl.Microbiol., 2014; 8(5): 3675.

10. Yandri, Suhartati T., Hadi S., Eur. J. Sci. Res, 2010; 39: 64.

11. Mandels M., Raymond A. and Charles R., Biotech. Bioeng. Symp., 1976; 6: 21.

12. Lowry O.H., Rosebrough N.J., Farr A.L. and Randall R.J., J. Biol. Chem., 1951; 193.

13. Kazan D., Ertan H. and Erarslan A., Process Biochem., 1996; 31: 135.

14. Synder, S.L. and Sobocinski, P.Z. Anal, Biochem., 1975; 64: 284.
15. Yang Z., Michael D., Robert A., Fang X.Y. and Alan J.R., Enzyme Microb. Technol., 1996; 18: 82.

16. Francis G.E., Delgado C. and Fisher D., PEG modified proteins in Stability of Protein Pharmaceuticals Part B (Ahern T J \& Manning M C, Eds), Plenum Press, New York, 1992; 246-247.

17. Stahl S., In: Thermostability of Enzymes (Gupta M.N., ed), Springer Verlag, New Delhi, 1999; 59-60. 